\title{
Kajian Ulang Penggunaan Media Digital Dalam Aktivitas Belajar Mengajar di Program Studi Teknik Industri
}

\author{
Review of the Use of Digital Media in Teaching and Learning Activities \\ at Bachelor Program in Industrial Engineering
}

\author{
Elty Sarvia, Andrijanto, Winda Halim, Muhammad Rafi \\ Fakultas Teknik, Program Studi Teknik Industri, Universitas Kristen Maranatha \\ E-mail: elty.sarvia@eng.maranatha.edu, andrijanto@eng.maranatha.edu, \\ winda.halim@eng.maranatha.edu,muhammadrafi388@gmail.com
}

\begin{abstract}
Abstrak
Penelitian ini bertujuan untuk melakukan evaluasi usability pada media digital yang digunakan sejak tahun 2014 sebagai sarana pendukung pembelajaraan di Program Studi Teknik Industri. Adapun media yang digunakan adalah blog dan course learning system (CLS). Blog digunakan sebagai media yang dinilai dapat menjembatani antara dosen dengan mahasiswa terkait informasi seputar perkuliahan. CLS digunakan sebagai media dosen untuk menyimpan materi perkuliahan, seperti teori dan modul praktikum, serta untuk mengadakan kuis online. Evaluasi usability akan mengukur media yang digunakan berdasakan kriteria learnability, efficiency, memorability, errors dan satisfaction. Hal ini dilakukan untuk menentukan pengembangan lebih lanjut media digital sebagai sarana komunikasi yang diwajibkan oleh pemerintah. Penelitian dilakukan dengan menyebarkan kuesioner selama tahun 2019 dengan metode sampling purposive kepada dosen yang telah menggunakan sarana media khususnya blog dan CLS untuk mendukung proses pengajaran yang dilakukan. Dari hasil kuesioner diperoleh bahwa 2 kriteria dari lima kriteria Nielsen di atas rata-rata keseluruhan (2,97) yaitu Efficiency (3,07) dan Satisfaction (3,00) yang mengindikasikan bahwa media digital blog sudah efisien dalam operasinya dan pengguna (dosen) cukup puas dalam menggunakan. Sedangkan untuk sistem e-learning CLS terdapat 3 kriteria di atas ratarata keseluruhan (2,72) yaitu Learnability $(2,74)$, Memorability $(2,77)$ dan Satisfaction $(2,8)$ yang mengindikasikan bahwa mudah dipelajari, mudah diingat dan pengguna (dosen) cukup puas dalam menggunakan. Semua dosen sudah puas terhadap semua variabel untuk keenam konten, akan tetapi pada sistem CLS, dosen berpendapat bahwa variabel 'Upload Latihan Soal' belum memenuhi prinsip Efficiency dan beberapa variabel 'Upload Latihan Soal' dan 'Info Tugas Kuliah' belum memenuhi prinsip usability.
\end{abstract}

Kata kunci: media digital, e-learning, Nielsen usability model

\begin{abstract}
This research is done to evaluate the usability of digital media that has been using in industrial engineering program study since the year 2014. There are two digital media, blog and course learning system (CLS). Blog is used to deliver the study information from lecturer to students. CLS is used to store course content such as theories and practice module, and also for conducting an online quiz. Usability evaluation will measure 5 criteria: learnability, efficiency, memorability, errors, and satisfaction. This evaluation will determine a digital media development in the future due to the new regulation of using online digital media for communication in high education. The questionnaire is distributed in 2019 with a purposive sampling method to lecturers who have used media facilities, especially blogs and CLS to support the teaching process carried out. From the results of the questionnaire, it was found that 2 of Nielsen's five criteria were above the overall average (2.97), namely Efficiency (3.07) and Satisfaction (3.00) which indicated that the digital media blog was efficient in its operations and users (Lecturers) quite satisfied in using. Whereas for the CLS e-learning system there are 3 criteria above the overall average (2.72), namely Learnability (2.74), Memorability (2.77) and Satisfaction (2.8) which indicate that it is easy to learn, easy to remember and users (lecturers) are quite satisfied in using. All Lecturers are satisfied with all
\end{abstract}




\section{KAJIAN ULANG PENGGUNAAN MEDIA DIGITAL (EIty S., dkk.)}

the variables for the six contents, but in the CLS system, the lecturer argues that the variable 'Upload Exercise Questions' has not fulfilled the Efficiency principle and several variables 'Upload Question Exercises' and 'Info on Classwork' do not meet the usability principle.

Keyword: digital media, e-learning, Nielsen usability model

\section{Pendahuluan}

Dewasa ini teknologi internet memiliki peranan yang sangat besar dalam mendukung alat komunikasi untuk menyampaikan informasi yang tidak dapat diabaikan di kehidupan modern. Penyampaian informasi dengan teknologi internet membuat lembaga pendidikan saat ini membutuhkan teknologi informasi dan pengembangan sumber daya manusia yang mampu menanggapi perkembangannya. E-learning merupakan penerapan teknologi informasi dalam dunia pendidikan untuk menyampaikan pembelajaran. E-learning sebagai komponen pembelajaran menggunakan berbagai aplikasi yang dijalankan pada media elektronik yang tersedia dalam institusi pendidikan, temasuk di dalamnya pembelajaran berbasis komputer, pembelajaran berbasis web, ruang kelas maya dan kolaborasi digital (Mason dan Rennie, 2010). Aplikasi e-learning umumnya terbagi menjadi dua kategori, yaitu offline learning, dan online learning (Srivastava dkk, 2009). Online learning mengacu pada pembelajaran menggunakan komputer dan jaringan internet pada media berbasis web, seperti virtual classrooms, digital collaboration (forum diskusi online, chat dan lain-lain) sedangkan offline learning mengacu pada pembelajaran menggunakan peralatan media digital seperti CD-ROM, DVD dan sebagainya.

Salah satu aspek yang dinilai penting bagi kualitas media pendukung pembelajaran adalah memenuhi prinsip usability. Prinsip usability menitikberatkan kepada kemudahan dari pengguna untuk dapat mengakses konten yang terdapat dalam media tersebut sehingga akhirnya tercapai kepuasan. Prinsip usability juga dapat menggambarkan proyeksi tentang kecocokan dan kemenarikan tampilan dari media tersebut bagi penggunanya, sehingga mampu memberikan masukan yang lebih inovatif (sumbernya). Media yang saat ini sering digunakan dalam kegiatan perkuliahan di lingkungan akademik adalah blog dan Course Learning System (CLS). Blog dan CLS digunakan sebagai media pendukung pembelajaran yang dinilai dapat menjembatani antara pengajar dengan siswa terkait informasi seputar pendidikan. Hal ini ditandai dengan banyaknya pengajar yang menyampaikan informasi-informasi dan materi pengajaran melalui blog dan CLS. Blog dan CLS juga dinilai sangat efisien karena dapat diakses dengan cepat dan mudah melalui smartphone serta komputer/laptop dimanapun dan kapanpun.

Pengembangan web-log bagi dosen di Program Studi Teknik Industri, Universitas Kristen Maranatha Bandung sudah dilakukan sejak tahun 2014. Hal tersebut merupakan upaya dari program studi untuk meningkatkan pelayanan informasi, khususnya dalam penyampaian materi perkuliahan ke mahasiswa, serta dukungan ke dosen yang berhubungan dengan penerapan Tridarma Perguruan Tinggi. Dosen dapat dengan mudah untuk meng-upload bahan perkuliahan dan soal latihan yang dapat digunakan para mahasiswa untuk proses belajar di dalam kelas. Selain itu, blog juga dimanfaatkan oleh dosen untuk dapat memberikan informasi terkait perkuliahan seperti jadwal kuliah, jadwal bimbingan, jadwal perwalian dan upload nilai ujian untuk setiap mata kuliah yang diajarkan. Meskipun kehadiran blog dosen sudah membantu, namun kenyataannya masih perlu dilakukan pengembangan dalam pelaksanaannya.

Selain blog, Universitas Kristen Maranatha (UKM) juga menyediakan CLS sejak tahun 2007, sebagai salah satu wadah dosen untuk menyimpan materi perkuliahan, baik teori ataupun praktikum, kuis online yang dapat diakses dan dimanfaatkan oleh mahasiswa yang sedang menempuh perkuliahan mata kuliah yang bersangkutan pada kelas dosen tersebut. Dalam hal ini ada 2 media yang dapat dipilih oleh dosen Program Studi Teknik Industri untuk menyampaikan informasi terkait dengan pengajaran. Berdasarkan hal tersebut maka dilakukan penelitian untuk mengetahui penilaian dosen terkait kedua platform media digital tersebut ditinjau dari sudut pandang dosen yang telah menggunakannya selama ini. 


\section{Metode Penelitian}

Dalam penelitian ini metode pengumpulan data yang digunakan adalah kuesioner dalam bentuk pernyataan. Skala pengukuran variabel dalam penelitian ini mengacu pada skala Likert yang masingmasing dibuat dengan menggunakan skala 1-4 kategori jawaban, hal ini dilakukan untuk menghindari jawaban ragu-ragu di bagian tengah skala yang akan membuat jawaban yang diterima terkesan kurang tegas atau menggantung. Adapun rincian penilaian skalanya adalah sebagai berikut: 'Sangat Tidak Setuju' diberi nilai 1, 'Tidak Setuju' diberi nilai 2, 'Setuju' diberi nilai 3 dan 'Sangat Setuju' diberi nilai 4.

Setelah data berupa kuesioner terisi dan terkumpul, maka akan dilakukan analisis deskriptif. Teknik sampling yang digunakan adalah Teknik Sampling Purposive. Sampling purposive adalah teknik penentuan sampel dengan pertimbangan tertentu (Sugiyono, 2010). Jadi kriteria sampel dalam penelitian ini adalah dosen yang pernah menggunakan blog dan/atau CLS. Kuesioner terbagi menjadi 2 jenis yaitu kuesioner untuk pengguna Blog dan kuesioner untuk penggunaan CLS. Jumlah responden dosen untuk kuesioner pengguna Blog adalah sebanyak 5 orang dan CLS adalah sebanyak 15 orang. Jumlah ini terbilang sedikit karena pada saat penelitian ini dilakukan penggunaan kedua media ini masih belum diwajibkan saat itu, sehingga belum banyak penggunanya. Masing-masing dosen akan menilai blog atau CLS yang mereka miliki dari berbagai aspek sesuai dengan komponen usability dari Jacob Nielsen yang telah dijelaskan. Survei dilakukan melalui penggunaan online platform Google Forms dan wawancara dengan beberapa dosen. Alasan menggunakan kriteria Nielsen ini adalah dikarenakan kelima kriteria tersebut yang paling dapat dirasakan pengguna dan di dalamnya memasukkan kriteria errors atau kesalahan. Karena dalam menggunakan sebuah sistem, hal yang lumrah jika seseorang melakukan kesalahan pada saat menggunakan sistem. Jika terdapat tingkat kesalahan penggunaan tinggi, menunjukkan rendahnya usability dari sistem tersebut. Data yang terkumpul kemudian hanya akan diuji secara deskriptif dikarenakan jumlah data yang diperoleh sangat sedikit. Berdasarkan hal tersebut kemudian akan dilakukan penilaian secara kualitatif dari masing-masing pendapat yang diberikan oleh pengguna baik untuk blog maupun CLS di Universitas Kristen Maranatha khususnya Program Studi Teknik Industri. Wawancara berfungsi sebagai informasi tambahan untuk menghasilkan lebih banyak bukti komprehensif untuk meningkatkan usability dari media digital yang digunakan. Metode yang digunakan adalah analisis statistika deskriptif.

Saat ini dosen Teknik Industri dalam proses belajar mengajar menggunakan 2 jenis sistem dalam yaitu sistem blog dosen dan sistem e-learning CLS. Penelitian ini dilakukan dengan melakukan perbandingan sarana pendukung pembelajaran yang telah diterapkan di UKM yaitu blog dosen dengan menggunakan platform blogger dan sistem e-learning CLS. Penilaian blog dilakukan hanya pada blog dosen di Program Studi Teknik Industri saja, sedangkan penilaian CLS dilakukan pada dosen-dosen yang pernah menggunakannya dari berbagai program studi yang terdapat di UKM.

Variabel dari kuesioner ditentukan berdasarkan model Jakob Nielsen, 2003 yang terdiri dari lima kriteria usability. Adapun kriteria usability yang di analisis tersebut terdiri dari enam konten yaitu:

1. Upload diktat kuliah

2. Upload latihan soal

3. Info kontak dosen

4. Upload nilai

5. Info tugas kuliah

6. Info referensi jurnal/materi perkuliahan

Seluruh task yang dikerjakan dievaluasi berdasarkan variabel-variabel yang merepresentasikan aspek Nielsen, terdiri dari Learnability, Efficiency, Memorability, Errors, dan Satisfaction yang dijadikan kuesioner dalam penelitian ini. Adapun skala penilaian yang digunakan untuk masingmasing variabel adalah menggunakan skala Likert 1-4. 


\section{KAJIAN ULANG PENGGUNAAN MEDIA DIGITAL (EIty S., dkk.)}

\section{Hasil dan Pembahasan}

Dalam penelitian ini akan dilihat secara umum apakah tingkat usability dari blog Program Studi Teknik Industri memenuhi kriteria usability menurut Jacob Nielsen atau tidak, maka kuesioner di bagi menjadi 2 jenis yaitu kuesioner untuk penggunaan blog dan kuesioner untuk penggunaan CLS. Masing-masing dosen akan menilai blog atau CLS yang mereka miliki dari berbagai aspek sesuai dengan komponen usability dari Jacob Nielsen yang telah dijelaskan. Seluruh butiran pada kuesioner adalah untuk mengevaluasi blog dosen dengan menggunakan skala penilaian Likert 1-4 yang digunakan untuk masing-masing variabel. Responden akan mengisi nilai 1 apabila dia 'sangat tidak setuju' dengan maksud pernyataan pada masing-masing variabel dan mengisi nilai 4 jika dia 'sangat setuju' dengan maksud penyataan pada masing-masing variabel.

\section{Sebaran Data dan Hasil Kuesioner Blog Dosen}

Dari gambar 1, terlihat jelas bahwa tingkat usability keseluruhan menunjukkan nilai 2,97 dari skala 1-4. Ini menunjukkan bahwa blog memiliki tingkat usability di atas rata-rata, pembelajaran digital sudah user friendly. Sementara masing-masing kriteria dalam aspek Nielsen seperti Efficiency $(3,07)$ dan Satisfaction $(3,00)$ mengindikasikan nilai aspek-aspek berada di atas rata-rata dari nilai pengukuran keseluruhan. Dari kondisi tersebut dapat disimpulkan beberapa poin, yaitu:

Tabel 1. Nilai Rata-rata Kriteria Aspek Nielsen Pada Blog

\begin{tabular}{|c|c|c|c|}
\hline Aspek Nielsen & Rata-rata & Standar De viasi & Median \\
\hline Keseluruhan Pengukuran & 2.97 & 0.196 & 3.00 \\
\hline Learnability & 2.92 & 0.239 & 3.00 \\
\hline Efficiency & 3.07 & 0.207 & 3.20 \\
\hline Memorability & 2.93 & 0.103 & 3.00 \\
\hline Error & 2.93 & 0.103 & 3.00 \\
\hline Satisfaction & 3.00 & & \\
\hline
\end{tabular}

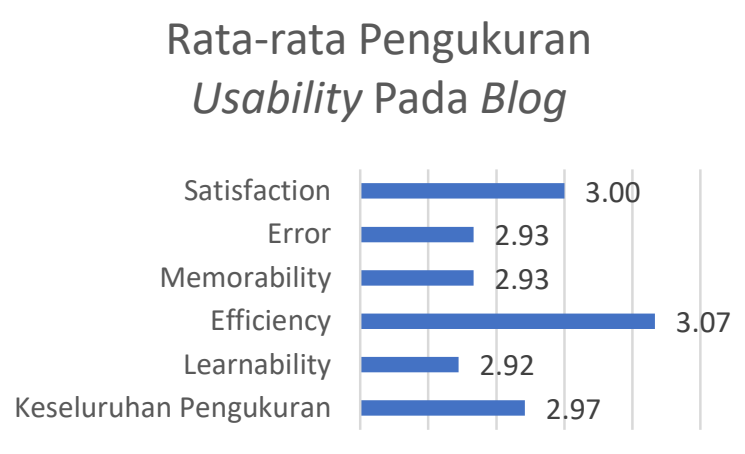

2.852 .902 .953 .003 .053 .10

Gambar 1. Perbandingan Kriteria Aspek Usability Nielsen Pada Blog Dosen

- Efficiency, dimana pengguna blog merasakan hasil dari mengoperasikan sistem yang memberikan hasil yang diharapkan (efficient) sehingga proses pembelajaran terasa lebih cepat. Dosen dapat memberikan materi perkuliahan, soal latihan dan pengumuman nilai secara mudah dan cepat, sehingga mahasiswa dapat mengakses dimanapun dia berada dan dapat diberikan sebelum adanya pertemuan langsung di kelas perkuliahan. Nilai aspek ini diperoleh dari rata-rata variabel X4, X10, X16, X22, X28 dan X34.

- Satisfaction, dari nilai aspek ini dapat disimpulkan bahwa konten yang ada pada blog secara keseluruhan dapat membuat responden cukup puas. Nilai aspek ini diperoleh dari rata-rata variabel X37.

Namun nilai rata-rata Learnability $(2,92)$, Memorability $(2,93)$ dan Error $(2,93)$ yang masih berada di bawah rata-rata keseluruhan, hal ini mengindikasikan bahwa konten pada blog masih terdapat beberapa kendala untuk dipelajari oleh dosen. 
- Learnability (2,92), dimana sistem tidak mudah dipelajari sehingga pengguna sedikit mengalami kesulitan dalam mengoperasikan.

Nilai learnability yang masih berada di bawah rata-rata keseluruhan, hal ini mengindikasikan bahwa konten pada blog masih terdapat beberapa kendala untuk dipelajari oleh responden. Bila diteliti lebih lanjut, variabel dalam learnability ini semuanya sudah berada di atas 2,5 dari skala Likert yang artinya bahwa pengguna sudah cukup puas dengan konten-konten pada blog. Hanya saja jika dibandingkan dengan nilai rata-rata keseluruhan nilai learnability ini masih di bawah 2,97, hal ini dikarenakan variabel X3, X9, X15, X20, X21, X25, X27 dan X33 yang masih di bawah nilai 3, yang menyebabkan nilai learnability menjadi di bawah 2,97. Variabel yang memiliki nilai di bawah 3 itu adalah mengenai pengguna (dosen) dalam mengoperasikan konten tertentu masih membutuhkan instruksi/bantuan orang lain terutama ketika pengguna baru pertama kali berhadapan dengan task tersebut. Walaupun sistem tersebut mudah dipelajari, sebaiknya dibuat user guide 'panduan penggunaan blog' yang ringkas untuk dapat dipelajari dengan mudah dan cepat oleh pengguna baru. Adapun variabel yang menyebabkan nilainya di bawah 2,97 adalah:

> X3: pengguna apalagi pengguna baru mengakses konten "upload diktat kuliah" masih memerlukan instruksi dari orang lain

> X9: pengguna apalagi pengguna baru mengakses konten "upload latihan soal" masih memerlukan instruksi dari orang lain

$>$ X15: pengguna apalagi pengguna baru mengakses konten "info kontak dosen" masih memerlukan instruksi dari orang lain

$>$ X20: pengguna apalagi pengguna baru mempelajari akses konten "upload nilai" masih mengalami kesulitan.

$>$ X21: pengguna apalagi pengguna baru mengakses konten "upload nilai" masih memerlukan instruksi dari orang lain

$>$ X25: pengguna apalagi pengguna baru mempelajari akses konten "upload info tugas kuliah" masih mengalami kesulitan.

$>$ X27: pengguna apalagi pengguna baru mengakses konten "upload info tugas kuliah" masih memerlukan instruksi dari orang lain

$>$ X33: pengguna apalagi pengguna baru mengakses konten "Info referensi jurnal/materi perkuliahan" masih memerlukan instruksi dari orang lain

- Memorability (2,93), dimana pengguna blog merasakan bahwa fungsi, fitur dan langkahlangkah untuk mengakses konten pada platform blogger beberapa sulit diingat pada saat dioperasikan, sehingga pengguna sedikit mengalami kesulitan setiap kali berinteraksi dengan antarmuka sistem. Nilai aspek ini diperoleh dari rata-rata variabel X5, X11, X17, X23, X29 dan X35. Adapun variabel yang menyebabkan nilainya di bawah 2,93 adalah:

> X5: pengguna apalagi pengguna baru masih mengalami kesulitan dalam mengingat langkah-langkah untuk mengakases konten "upload diktat kuliah".

$>$ X11: pengguna apalagi pengguna baru masih mengalami kesulitan dalam mengingat langkah-langkah untuk mengakases konten "upload latihan Soal".

$>$ X17: pengguna apalagi pengguna baru masih mengalami kesulitan dalam mengingat langkah-langkah untuk mengakases konten "info kontak dosen".

$>$ X23: pengguna apalagi pengguna baru masih mengalami kesulitan dalam mengingat langkah-langkah untuk mengakases konten "upload nilai".

$>$ X29: pengguna apalagi pengguna baru masih mengalami kesulitan dalam mengingat langkah-langkah untuk mengakases konten "info tugas kuliah".

> X35: pengguna apalagi pengguna baru masih mengalami kesulitan dalam mengingat langkah-langkah untuk mengakases konten "info referensi jurnal/materi perkuliahan".

- Error (2,53), dimana blog menunjukkan kesalahan yang dialami oleh pengguna ketika diakses. Hal ini menunjukkan kesalahan yang sering ditemui oleh pengguna merupakan kesalahan kecil dan pengguna dapat mengatasinya sendiri. Nilai aspek ini diperoleh dari rata-rata variabel X6, X12, X18, X24, X30 dan X36. Adapun variabel yang menyebabkan nilainya di bawah 2,93 adalah: 
KAJIAN ULANG PENGGUNAAN MEDIA DIGITAL (Elty S., dkk.)

X6: pengguna apalagi pengguna baru masih mengalami kesulitan atau menemukan kesalahan kecil dalam menemukan konten "upload diktat kuliah".

$>$ X12: pengguna apalagi pengguna baru masih mengalami kesulitan atau menemukan kesalahan kecil dalam menemukan konten "upload latihan soal".

$>$ X18: pengguna apalagi pengguna baru masih mengalami kesulitanatau menemukan kesalahan kecil dalam menemukan konten "info kontak dosen".

$>$ X24: pengguna apalagi pengguna baru masih mengalami kesulitan atau menemukan kesalahan kecil dalam menemukan konten "upload nilai".

$>$ X30: pengguna apalagi pengguna baru masih mengalami kesulitan atau menemukan kesalahan kecil dalam menemukan konten "info tugas kuliah"

$>$ X36: pengguna apalagi pengguna baru masih mengalami kesulitan atau menemukan kesalahan kecil dalam menemukan konten "info referensi jurnal/materi perkuliahan".

Tabel 2. Penentuan Lebar Interval

\begin{tabular}{|c|c|}
\hline Lebar Interval & $\mathbf{0 . 7 5}$ \\
\hline Interval & Arti \\
\hline $1 \leq \mathrm{X} \leq 1.75$ & Sangat Tidak Setuju \\
\hline $1.76 \leq \mathrm{X} \leq 2.51$ & Tidak Setuju \\
\hline $2.52 \leq \mathrm{X} \leq 3.27$ & Setuju \\
\hline$>3.27$ & Sangat Setuju \\
\hline
\end{tabular}

Tabel 3. Rekapitulasi Nilai Rata-rata Kuesioner Blog Dosen TI

\begin{tabular}{|c|c|c|c|c|c|}
\hline No & Konten & $\begin{array}{c}\text { Aspek dalam } \\
\text { Model Nielsen } \\
\end{array}$ & $\begin{array}{c}\text { Nilai } \\
\text { Rata-Rata } \\
\end{array}$ & $\begin{array}{l}\text { Rangkuman } \\
\text { Blog } \\
\end{array}$ & Usability \\
\hline \multirow{6}{*}{1} & \multirow{6}{*}{ Upload diktat kuliah } & \multirow{3}{*}{ Learnability (X1-X3) } & 3.20 & Para responden setuju bahwa akses konten pada Blog mudah untuk & $\mathrm{V}$ \\
\hline & & & 3.00 & Para responden setuju bahwa langkah-langkah penerapan konten pada Blog & $\mathrm{V}$ \\
\hline & & & 2.60 & Para responden setuju bahwa penerapan konten pada Blog dapat dipelajari & $\mathrm{V}$ \\
\hline & & Efficiency (X4) & 3.20 & Para responden setuju bahwa akses konten pada Blog cepat & $\mathrm{V}$ \\
\hline & & Memorability (X5) & 3.00 & Para responden setuju bahwa langkah-langkah untuk mengakses konten & $\mathrm{V}$ \\
\hline & & Errors (X6) & 3.00 & Para responden setuju bahwa konten pada Blog mudah diterapkan & $\mathrm{V}$ \\
\hline \multirow{6}{*}{2} & \multirow{6}{*}{ Upload Latihan Soal } & \multirow{3}{*}{ Learnability (X7-X9) } & 3.40 & Para responden setuju bahwa akses konten pada Blog mudah untuk & $\mathrm{V}$ \\
\hline & & & 3.00 & Para responden setuju bahwa langkah-langkah penerapan konten pada Blog & $\mathrm{V}$ \\
\hline & & & 2.60 & Para responden setuju bahwa penerapan konten pada Blog dapat dipelajari & $\mathrm{V}$ \\
\hline & & Efficiency (X10) & 3.20 & Para responden setuju bahwa akses konten pada Blog cepat & $\mathrm{V}$ \\
\hline & & Memorability (X11) & 3.00 & Para responden setuju bahwa langkah-langkah untuk mengakses konten & $\mathrm{V}$ \\
\hline & & Errors (X12) & 3.00 & Para responden setuju bahwa konten pada Blog mudah diterapkan & $\mathrm{V}$ \\
\hline \multirow{6}{*}{3} & \multirow{6}{*}{ Kontak Dosen } & \multirow{3}{*}{ Learnability (X13-X15) } & 3.20 & Para responden setuju bahwa akses konten pada Blog mudah untuk & $\mathrm{V}$ \\
\hline & & & 3.00 & Para responden setuju bahwa langkah-langkah penerapan konten pada Blog & $\mathrm{V}$ \\
\hline & & & 2.80 & Para responden setuju bahwa penerapan konten pada Blog dapat dipelajari & $\mathrm{V}$ \\
\hline & & Efficiency (X16) & 3.20 & Para responden setuju bahwa akses konten pada Blog cepat & $\mathrm{V}$ \\
\hline & & Memorability (X17) & 3.00 & Para responden setuju bahwa langkah-langkah untuk mengakses konten & $\mathrm{V}$ \\
\hline & & Errors (X18) & 3.00 & Para responden setuju bahwa konten pada Blog mudah diterapkan & $\mathrm{V}$ \\
\hline \multirow{6}{*}{4} & \multirow{6}{*}{ Upload Nilai } & \multirow{3}{*}{ Learnability (X19-X21) } & 3.00 & Para responden setuju bahwa akses konten pada Blog mudah untuk & $\mathrm{V}$ \\
\hline & & & 2.80 & Para responden setuju bahwa langkah-langkah penerapan konten pada Blog & $\mathrm{V}$ \\
\hline & & & 2.60 & Para responden setuju bahwa penerapan konten pada Blog dapat dipelajari & $\mathrm{V}$ \\
\hline & & Efficiency (X22) & 2.80 & Para responden setuju bahwa akses konten pada Blog cepat & $\mathrm{V}$ \\
\hline & & Memorability (X23) & 2.80 & Para responden setuju bahwa langkah-langkah untuk mengakses konten & $\mathrm{V}$ \\
\hline & & Errors (X24) & 2.80 & Para responden setuju bahwa konten pada Blog mudah diterapkan & $\mathrm{V}$ \\
\hline \multirow{6}{*}{5} & \multirow{6}{*}{ Info Tugas Kuliah } & \multirow{3}{*}{ Learnability (X25-X27) } & 3.00 & Para responden setuju bahwa akses konten pada Blog mudah untuk & $\mathrm{V}$ \\
\hline & & & 2.80 & Para responden setuju bahwa langkah-langkah penerapan konten pada Blog & $\mathrm{V}$ \\
\hline & & & 2.60 & Para responden setuju bahwa penerapan konten pada Blog dapat dipelajari & $\mathrm{V}$ \\
\hline & & Efficiency (X28) & 2.80 & Para responden setuju bahwa akses konten pada Blog cepat & $\mathrm{V}$ \\
\hline & & Memorability (X29) & 2.80 & Para responden setuju bahwa langkah-langkah untuk mengakses konten & $\mathrm{v}$ \\
\hline & & Errors (X30) & 2.80 & Para responden setuju bahwa konten pada Blog mudah diterapkan & $\mathrm{V}$ \\
\hline \multirow{6}{*}{6} & \multirow{6}{*}{$\begin{array}{c}\text { Referensi Jurnal/Materi } \\
\text { Perkuliahan }\end{array}$} & \multirow{6}{*}{ Learnability (X31-X33) } & 3.20 & Para responden setuju bahwa akses konten pada Blog mudah untuk & $\mathrm{V}$ \\
\hline & & & 3.00 & Para responden setuju bahwa langkah-langkah penerapan konten pada Blog & $\mathrm{V}$ \\
\hline & & & 2.80 & Para responden setuju bahwa penerapan konten pada Blog dapat dipelajari & $\mathrm{V}$ \\
\hline & & & 3.20 & Para responden setuju bahwa akses konten pada Blog cepat & $\mathrm{V}$ \\
\hline & & & 3.00 & Para responden setuju bahwa langkah-langkah untuk mengakses konten & $\mathrm{V}$ \\
\hline & & & 3.00 & Para responden setuju bahwa konten pada Blog mudah diterapkan & $\mathrm{V}$ \\
\hline
\end{tabular}


Arti dari penarikan kesimpulan pada tabel 3. adalah untuk mengetahui rata-rata jawaban para responden terhadap variabel tersebut. Kesimpulan didapatkan dari hasil interpretasi terhadap interval yang dijelaskan pada tabel 2. Untuk itu, dapat disimpulkan bahwa semua konten sudah memenuhi prinsip usability, berdasarkan hasil pengolahan bahwa semua responden setuju bahwa enam konten tersebut memenuhi lima aspek Nielsen.

\section{Sebaran Data dan Hasil Kuesioner CLS}

Tabel 4 adalah rekapitulasi hasil dari kuesioner bagi dosen-dosen yang pernah menggunakan sistem e-learning CLS yang telah disebarkan.

Tabel 4. Rekapitulasi Nilai Rata-rata Kuesioner $C L S$

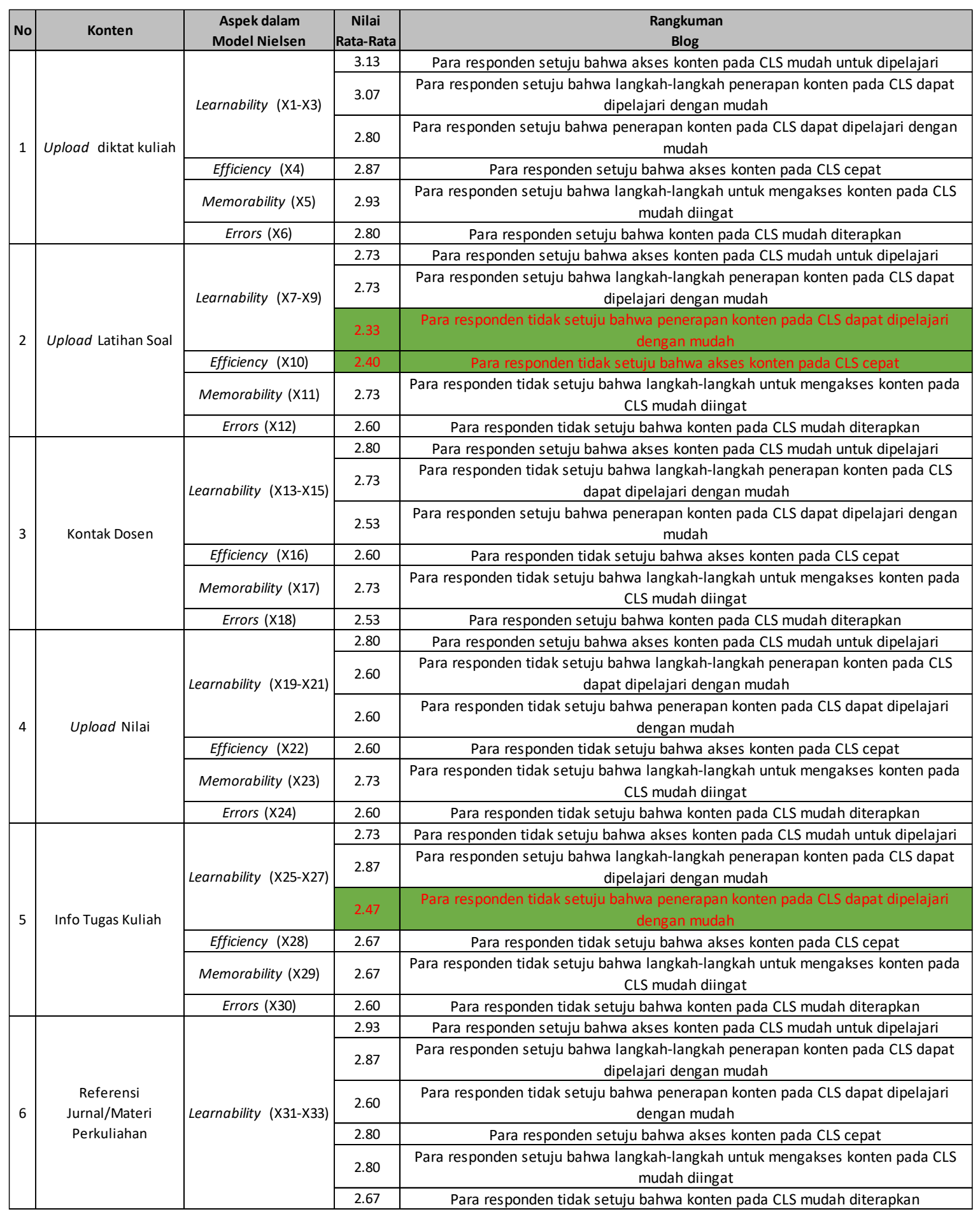




\section{KAJIAN ULANG PENGGUNAAN MEDIA DIGITAL (Elty S., dkk.)}

Penilaian CLS disebarkan kepada dosen-dosen di Universitas Kristen Maranatha yang pernah menggunakan sistem e-learning ini. Data sebaran kuesioner untuk setiap jurusan/program studi:

Tabel 5. Sebaran Data Kuesioner

\begin{tabular}{|c|c|}
\hline Jurusan & Responden \\
\hline Akuntansi & 1 \\
\hline Desain Interior & 1 \\
\hline Manajemen & 6 \\
\hline Psikologi & 1 \\
\hline Seni Rupa dan Desain & 1 \\
\hline Teknik Industri & 1 \\
\hline Teknik Informatika & 4 \\
\hline Total Responden & $\mathbf{1 5}$ \\
\hline
\end{tabular}

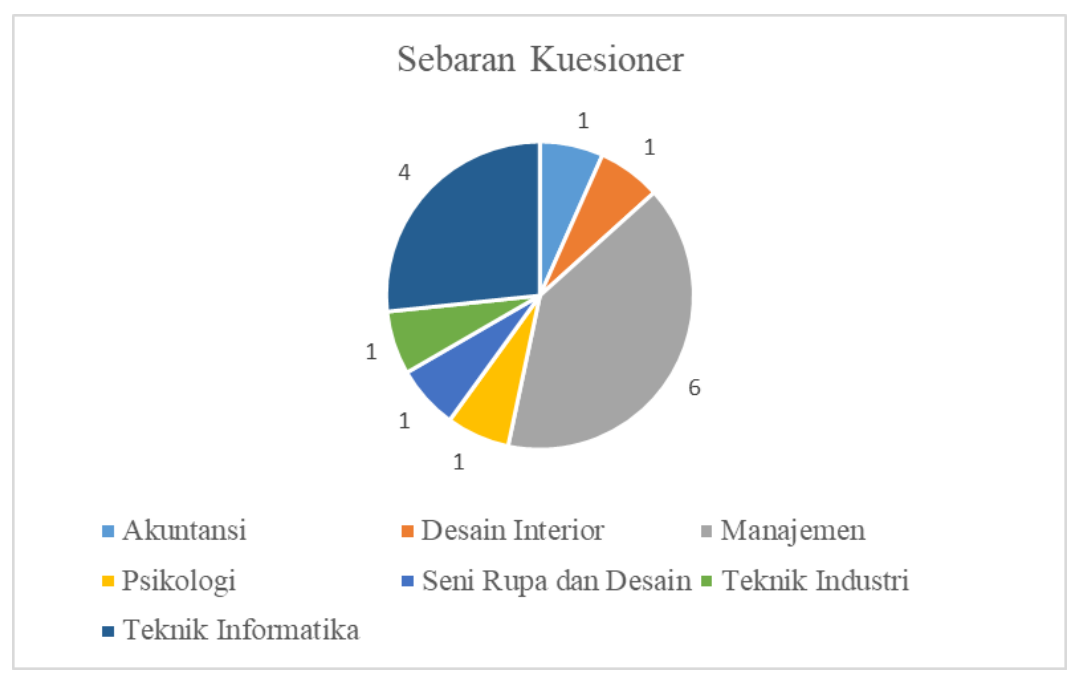

Gambar 2. Pie Chart Sebaran Data Kuesioner

Dalam penelitian ini akan dilihat apakah secara umum tingkat usability dari CLS yang digunakan oleh dosen-dosen di Universitas Kristen Maranatha memenuhi kriteria usability menurut Jacob Nielsen. Hasil perhitungan rata-rata dari masing-masing kriteria aspek Nielsen dapat dilihat pada tabel di bawah ini:

Tabel 6. Nilai Rata-rata Kriteria Aspek Nielsen Pada CLS

\begin{tabular}{|c|c|c|c|}
\hline Aspek Nielsen & Rata-rata & Standar Deviasi & Median \\
\hline Keseluruhan Pengukuran & 2.72 & 0.169 & 2.73 \\
\hline Learnability & 2.74 & 0.201 & 2.73 \\
\hline Efficiency & 2.66 & 0.166 & 2.63 \\
\hline Memorability & 2.77 & 0.092 & 2.73 \\
\hline Error & 2.63 & 0.092 & 2.60 \\
\hline Satisfaction & 2.80 & & \\
\hline
\end{tabular}




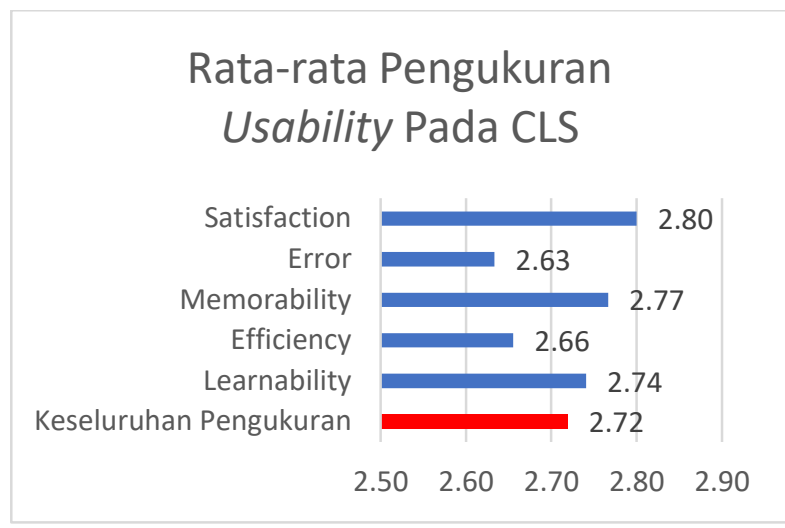

Gambar 3. Perbandingan Kriteria Aspek Usability Nielsen Pada CLS

Dari gambar 3, terlihat jelas bahwa tingkat usability keseluruhan menunjukkan nilai 2,72 dari skala 1-4. Ini menunjukkan bahwa CLS memiliki tingkat usability baik (di atas rata-rata 2,5), sehingga dapat dikatakan CLS yang digunakan Dosen sebagai sarana pendukung media pembelajaran digital sudah user friendly. Sementara masing-masing kriteria dalam aspek Nielsen seperti learnability $(2,74)$, memorability $(2,77)$, dan satisfaction $(2,80)$ mengindikasikan nilai di atas keseluruhan pengukuran, sehingga CLS sebagai media digital dalam aktivitas pembelajaran dapat dikatakan:

- Learnability, dimana pengguna tidak mengalami kesulitan pada saat mengoperasikan CLS. Hal tersebut dikarenakan pengguna sudah mengikuti training CLS terlebih dahulu. Dalam kuesioner, nilai variabel ini didapat dari rata-rata jawaban atas pernyataan variabel X1-X3, X7-X9, X13-15, X19-X21, X25-X27dan X31-X33.

- Memorability, dimana pengguna CLS merasakan bahwa fungsi, fitur dan langkah-langkah untuk mengakses konten pada platform CLS mudah diingat pada saat dioperasikan. Nilai dari variabel ini rata-rata dari X5, X11, X17, X23, X29 dan X35.

- Satisfaction, dimana pengguna puas dengan konten yang ada pada CLS secara keseluruhan. Nilai dari variabel ini rata-rata dari X37.

Namun nilai rata-rata efficiency $(2,66)$ dan error $(2,63)$ yang masih berada di bawah rata-rata keseluruhan, hal ini mengindikasikan bahwa konten pada CLS masih belum memberikan hasil yang diharapkan oleh pengguna (dosen) seperti proses yang lebih cepat dalam menyelesaikan task. Hal ini terlihat pada saat awal memulai CLS, terdapat beberapa prosedur yang cukup panjang, seperti dosen sebagai pengguna harus mendaftarkan email, dosen harus mendaftarkan nama-nama mahasiswa yang akan ikut di dalam kelasnya ke tenaga administrasi yang mengelola CLS ini. Prosedur tersebut membutuhkan waktu beberapa hari, sehingga tidak efisien. Selain itu juga ditemukan error pada saat menginput beberapa operasi pada halaman CLS, dan sistem tidak memberikan pesan kesalahan yang menyebabkan pengguna tidak menyadari kesalahan yang terjadi. Hal tersebut dapat ditemukan pada saat penginputan informasi mengenai perkulaiahn seperti capaian pembelajaran, deskripsi mata kuliah, dan referensi jurnal/materi perkuliahan harus dibuka dari Firefox. Bila tidak dibuka dari Firefox, apabila terjadi kesalahan pengetikan dan akan di-edit, tidak bisa dilakukan oleh dosen. dosen harus meminta bantuan tenaga administrasi untuk mereset data tersebut, baru bisa diperbaiki setelahnya, sehingga hal ini menjadi tidak efisien dari segi waktu dan prosedur.

Bila diteliti lebih lanjut, beberapa nilai variabel dalam learnability berada di bawah rata-rata yaitu 2.5 dari skala Likert yaitu variabel X9 dan X27. Mayoritas pengguna (dosen) saat menerapkan konten 'upload latihan soal' (X9), dan 'info tugas kuliah' (X27) pada CLS masih perlu menggunakan instruksi dari orang lain. Tingkat kemampuan pengguna untuk memahami sistem CLS terbantu dengan adanya 'panduan pengguna CLS'. Akan tetapi untuk ke 2 variabel di atas belum ada di 'panduan pengguna CLS'. Panduan pengguna berisi panduan dalam mengakses sistem informasi yang disediakan, apabila pengguna mempelajari panduan pengguna terlebih dahulu, maka secara praktis pengguna diharapkan dapat mengoperasikan suatu sistem dengan baik. Selain itu, pengguna 


\section{KAJIAN ULANG PENGGUNAAN MEDIA DIGITAL (EIty S., dkk.)}

mampu mempelajari sistem tersebut dengan cepat apabila panduannya berisi arahan yang jelas, mudah dipahami dan diberikan training terlebih dahulu.

Terdapat 1 nilai variabel pada aspek efficiency yang dibawah rata-rata 2,5 yaitu variabel X10. Mayoritas pengguna (dosen) cenderung merasa bahwa saat menerapkan konten 'upload latihan soal' pada CLS membutuhkan langkah-langkah yang panjang (tidak efisien). Untuk dapat memenuhi nilai efficient to use, pengguna dengan cepat dapat menyelesaikan task pada saat pertama kali mempelajari sistem tersebut (Rahadi, 2014). Pengguna dapat dengan cepat menyelesaikan task apabila telah mampu menentukan dengan tepat menu yang digunakan untuk menyelesaikan task, sehingga pengguna tidak perlu mencari menu terlebih dahulu saat akan menyelesaikan task. Nielsen menambahkan, ketika pengguna tiba di node, pengguna dengan cepat dapat menyesuaikan diri dan memahami makna dari node dalam kaitannya dengan titik keberangkatan mereka (Nielsen, 1995), yang artinya pengguna dapat dengan cepat menentukan menu yang dibutuhkannya untuk menyelesaikan task. Pada saat langkah-langkah dalam upload, pengguna merasakan bahwa terdapat langkah-langkah yang terlalu banyak dan tidak efisien, sehingga perlu dikaji ulang kembali sistem navigasi pada desain interface pada task ini.

Arti dari penarikan kesimpulan pada tabel 7 adalah untuk mengetahui rata-rata jawaban para responden terhadap variabel tersebut. Kesimpulan didapatkan dari hasil interpretasi terhadap interval yang dijelaskan pada tabel 2 Untuk itu, dapat disimpulkan bahwa beberapa konten CLS belum memenuhi prinsip usability, yaitu konten 'upload latihan soal' belum memenuhi prinsip efficiency dan beberapa variabel seperti X9 dan X27 pada konten 'upload latihan soal' dan 'info tugas kuliah' juga belum memenuhi prinsip usability.

Dari tabel rangkuman pada tabel 7., terlihat bahwa masih terdapat 3 variabel yang masih di bawah nilai rata-rata dari 2,5 yaitu X9, X10, dan X27. Kekurangan yang ditemukan selama penelitian ini, dapat disimpulkan dalam tabel 7.

Tabel 7. Variabel yang perlu ditingkatkan dalam Sistem CLS

\begin{tabular}{|c|c|c|c|c|c|}
\hline Konten & Aspek Nielsen & Nilai Rata-Rata & Variabel yang perlu di evaluasi & Kendala & Solusi \\
\hline Upload Diktat Kuliah & & & & & \\
\hline \multirow[t]{2}{*}{ Upload Latihan Soal } & Learnability & 2,33 & $\begin{array}{c}\text { Para responden tidak setuju } \\
\text { bahwa penerapan konten pada } \\
\text { CLS dapat dipelajari dengan } \\
\text { mudah (X9) }\end{array}$ & $\begin{array}{l}\text { Sistem informasi CLS belum } \\
\text { mampu dipahami pengguna, hal } \\
\text { ini mungkin konten 'Upload } \\
\text { latihan soal' (X9), pada CLS } \\
\text { belum ada di 'Panduan } \\
\text { Pengguna CLS'. }\end{array}$ & $\begin{array}{l}\text { Perlu dibuat panduan } \\
\text { mengenai 'Info Tugas } \\
\text { Kuliah' (X27) pada CLS } \\
\text { dan diberikan training } \\
\text { terlebih dahulu. }\end{array}$ \\
\hline & Efficiency & 2,40 & $\begin{array}{c}\text { Para responden tidak setuju } \\
\text { bahwa akses konten pada CLS } \\
\text { cepat (X10) }\end{array}$ & $\begin{array}{c}\text { Membutuhkan langkah-langkah } \\
\text { yang panjang (tidak efisien) }\end{array}$ & $\begin{array}{c}\text { Mengatur kembali sistem } \\
\text { navigasi pada desain } \\
\text { interface }\end{array}$ \\
\hline \multicolumn{6}{|l|}{ Info Kontak Dosen } \\
\hline \multicolumn{6}{|l|}{ Upload nilai } \\
\hline Info tugas kuliah & Learnability & 2,47 & $\begin{array}{c}\text { Para responden tidak setuju } \\
\text { bahwa penerapan konten pada } \\
\text { CLS dapat dipelajari dengan } \\
\text { mudah (X27) }\end{array}$ & $\begin{array}{l}\text { Sistem informasi CLS belum } \\
\text { mampu dipahami pengguna, hal } \\
\text { ini mungkin konten 'Info Tugas } \\
\text { Kuliah' (X27) pada CLS } \\
\text { belum ada di 'Panduan } \\
\text { Pengquna CLS' }\end{array}$ & $\begin{array}{l}\text { Perlu dibuat panduan } \\
\text { mengenai 'Info Tugas } \\
\text { Kuliah' (X27) pada CLS } \\
\text { dan diberikan training } \\
\text { terlebih dahulu. }\end{array}$ \\
\hline $\begin{array}{c}\text { Info referensi jurnal/materi } \\
\text { perkuliahan }\end{array}$ & & & & & \\
\hline
\end{tabular}

\section{Simpulan}

Berdasarkan nilai-nilai rata-rata pada aspek Nielsen pada blog dosen dapat disimpulkan blog dosen telah memenuhi prinsip usability (user friendly) dan pengguna (dosen) cukup puas dalam menggunakan sistem tersebut. Sedangkan pada CLS yang merupakan media digital sebagai sistem e-learning yang digunakan dalam aktivitas belajar mengajar juga telah memenuhi prinsip usability (user friendly) dan pengguna (dosen) cukup puas dalam menggunakan sistem tersebut. Akan tetapi masih terdapat 3 variabel yang perlu diperbaiki yaitu sistem informasi CLS belum mampu dipahami 
pengguna, hal ini mungkin karena konten 'upload latihan soal' (X9) pada CLS belum ada di 'panduan pengguna CLS'; membutuhkan langkah-langkah yang panjang (tidak efisien) dalam konten "upload latihan soal" (X10); dan sistem informasi CLS belum mampu dipahami pengguna, hal ini mungkin karena konten 'info tugas kuliah' (X27) pada CLS belum ada di 'panduan pengguna CLS'.

Beberapa kelebihan yang dimiliki blog adalah sistem efisien dalam operasinya dan pengguna (dosen) cukup puas dalam menggunakannya. Semua dosen yang menjadi responden dalam penelitian ini sudah puas terhadap semua variabel untuk keenam konten, semua pengguna dan memiliki link akan mudah dalam mengakses masuk ke blog, tanpa harus mendaftarkan terlebih dahulu ke tenaga administrasi.

Sedangkan beberapa kekurangan dari blog antara lain adalah belum adanya konten 'lihat nilai', sehingga perlu adanya penambahan konten 'lihat nilai' atau link untuk dosen yang belum menerapkan, belum adanya konten 'lihat referensi jurnal/materi perkuliahan', sehingga perlu adanya konten ' lihat referensi jurnal/materi perkuliahan' atau diberikan link untuk dosen yang belum menerapkan, belum adanya konten 'lihat kontak dosen', sehingga perlu adanya penambahan konten 'lihat kontak dosen' perlu ditambahkan email dan nomor telepon untuk dosen yang belum menerapkan, belum dapat dilakukan quiz online pada blog, belum bisa meng-upload tugas yang sudah dikerjakan oleh mahasiwa seperti di Google Classroom, belum bisa link ke email mahasiswa bila ada pemberitahuan/perubahan dalam sistem yang perlu diumumkan

Beberapa kelebihan yang dimiliki CLS, antara lain dari lima kriteria Nielsen, 3 kriteria di atas ratarata keseluruhan yaitu learnability, memorability dan satisfaction yang mengindikasikan bahwa mudah dipelajari, mudah diingat dan pengguna (dosen) cukup puas dalam menggunakan, dosen berpendapat bahwa variabel 'upload latihan soal' belum memenuhi prinsip efficiency dan beberapa variabel seperti X9 dan X27 pada konten 'upload latihan soal' dan 'info tugas kuliah' juga belum memenuhi prinsip usability, sudah dapat dilakukan quiz online pada sistem.

Beberapa kekurangan dari CLS, antara lain sistem informasi CLS belum mampu dipahami pengguna, hal ini mungkin karena konten 'upload latihan soal' (X9), 'info tugas kuliah' (X27) pada CLS belum ada di 'panduan pengguna CLS', beberapa konten seperti 'upload latihan soal' masih tidak efisien sehingga membutuhkan langkah-langkah yang panjang (tidak efisien), prosedur yang masih panjang yaitu harus mendaftarkan nama-nama mahasiswa yang ikut di kelas dosen pada semester bersangkutan kepada tenaga administrasi CLS, belum bisa meng-upload tugas yang sudah dikerjakan oleh mahasiwa seperti di Google Classroom, belum bisa link ke email mahasiswa bila ada pemberitahuan/perubahan dalam sistem yang perlu diumumkan.

\section{Daftar Pustaka}

A. Bojko (2013), Eye Tracking The User Experience, New York: Rosenfeld Media.

B. M. Subraya (2006), Integrated Approach to Web Performance Testing, My Sore: IGI Global.

H. Belson and J. Ho (2012), A Fresh Graduate's Guide to Software Development Tools and Technologies, Vol. 2nd, pp. 1-28.

Mason, R. and Rennie, F. (2010), Elearning: Panduan Lengkap Memahami Dunia Digital dan Internet. Jogjakarta.

J. Nielsen (1994), Usability Engineering Academic Press INC ed.

Nielsen, J. (1995). Multimedia and Hypertext, Boston: AP Professional.

Rahadi, Dedi Rianto(2014), Pengukuran Usability Sistem Menggunakan Use Questionnaire Pada Aplikasi Android, Jurnal Sistem Informasi (JSI), 6 (1), April: 661-671. 


\section{KAJIAN ULANG PENGGUNAAN MEDIA DIGITAL (EIty S., dkk.)}

Srivastava, S., Chandra, S. and Lam, H. (2009), Usability Evaluation of E-Learning Systems, [online] In: Khosrow-Pour, M., Khosrow-Pour, M. (eds.) Encyclopedia of Information Science and Technology, 2nd edn. IGI Global, Hershey, USA.

S. Dahal, Eye Don't Lie (2011), Understanding First Impression on Website Design Using Eye Tracking, Missouri S\&T Researhers.

Sugiyono (2010), Metode Penelitian Bisnis, Alfabeta, Bandung.

http://www.academia.edu/2833451/Usability_Evaluation_of_E-Learning_Systems 